\title{
EDITORIAL
}

\section{The Autonomous University in Contemporary Society}

\section{INTRODUCTION}

The articles in this issue are based on selected papers presented at the Seventh Annual International Conference on Higher Education (ICHE) in Marseilles, France in September 1994, where the theme was 'Managing the Autonomous University'. Most of the following articles have been greatly shortened and edited to fit within the limits of this special issue. If readers are interested in a given topic or author, they are urged to write to the authors for copies of the full papers presented at Marseilles. We wish to thank the leadership of ICHE for their assistance during the editing of this edition of Higher Education Policy and particularly want to thank Guy Neave, Editor of Higher Education Policy, for making this special issue possible.

\section{OVERVIEW OF THE ARTICLES}

The first three articles explore the broad meanings of autonomy and the contexts within which it is exercised in universities. The keynote addresses by Daxner and Andersson point out the many philosophical and practical issues associated with the concept of an autonomous university. They note that autonomy is never absolute but is affected by the particular historical and cultural context in individual nations. Daxner describes the tension between a university's maintaining its historical mission while at the same time adapting to society's changing demands. He lists five elements involved in mediating between the special characteristics of universities and the demands of the external system affecting higher education.

Anderson observes that constraints on government funding have contributed to universities gaining more autonomy. He traces developments affecting autonomy since World War II and describes the effects on universities of increasing knowledge, demands to study current societal problems, competitive pressures, life-long learning, lessening dependency on government funding, and demands for accountability. Anderson then discusses the need for flexible planning, being responsive to students, balancing research priorities, and ensuring integrity and ethical behaviour. He concludes with observations on the characteristics of university organisation and management necessary to sustain their autonomy.

The article by Wasser analyses different concepts of autonomy and, again, notes that it is contextually and politically defined with the state setting the outer limits within which it may be exercised. He reviews trends in the extent of autonomy granted institutions in Europe and examines the relationship between autonomy and management.

The next two articles discuss Canada's trends in autonomy. The article by Buchbinder and Rajagopal speculates on the effects that globalization, deficit reduction, managerial centralization, and the increasing use of information technology will have on the autonomy of Canadian universities. These political and economic trends undoubtedly have ramifications for other countries as well. They foresee a number of contradictory forces affecting institutional autonomy and express some apprehension about their consequences. George and McAllister examine the 'accountability movement' in Canada and review trends in institutional autonomy in several Canadian provinces; in particular, Ontario. They conclude that there is a fundamental dichotomy between the public's satisfaction with Canadian universities, as revealed by surveys, and public officials' demands for greater university accountability.

The next three articles review developments affecting institutional autonomy in Austria, Australia, and Turkey. Bast describes a major revision of the laws governing higher education in Austria that have significantly increased university decision-making power. Wilson reviews Australia's government-imposed quality assessment system for higher education institutions. He observes that this process, after two years, has resulted in significant changes in university internal processes and attitudes but believes it has not infringed on institutional autonomy. Saglam describes a 1981 reform law that has restructured Turkey's system of higher education, creating a Council responsible for nationwide governance of higher education. He believes this 'buffer' body, between government and universities, has increased university autonomy and has contributed to the growth and efficiency of higher education in Turkey.

The final two articles consider autonomy in particular settings. Denton and Kellett analyse the effects that the United Kingdom's national system of collective bargaining has on personnel practices and the effectiveness of universities. They believe that the current process leads to low staff morale and creates negative incentives for the effective management of universities. Nevertheless, they believe university management could take greater leadership in 
improving conditions within the confines of the current government process. Brown and Wolf describe a structure and process for granting greater autonomy to units within a university. De Montfort University, in the United Kingdom, gives academic faculty an unusually high degree of autonomy in making resource decisions. They believe their university has benefited greatly by adopting this highly decentralized approach to planning and governance.

Frank Schmidtlein

Toby Milton 